ISSN (print): 2644-0490, ISSN (online): 2644-0504

Volume 4 Issue 11 November 2021

Article DOI: 10.47191/jefms/v4-i11-15, Impact Factor: 6.228

Page No. 2236-2242

\title{
Women Empowerment through the Development of Family Entrepreneurship towards a Creative Economy, Puger District, Jember Regency
}

\author{
Nuruni Ika K $\mathbf{W}^{1}$, Ignatia Martha $\mathbf{H}^{2}$, Iwan Kresna Setiadi ${ }^{3}$ \\ ${ }^{1,2}$ Management Faculty of Economics and Business, UPN Veteran Jawa Timur, Indonesia \\ ${ }^{3}$ Management Faculty of Economics and Business, UPN Veteran Jakarta, Indonesia
}

ABSTRACT: The purpose of this study is to find out how the potential and opportunities that women have and the obstacles faced by women, as well as to find out how the model of women's empowerment in Mojosari village, Puger district, Jember district. This study is intended to describe the profile of women traders in developing entrepreneurship towards a local potential-based Creative Economy in Puger District, Jember Regency. The data of this study consisted of primary and secondary data. The data analysis technique uses an interactive model of analysis which has three components, namely data reduction, data presentation, and conclusion drawing.

KEYWORDS: Women Empowerment, Entrepreneurship. Creative Economy.

\section{INTRODUCTION}

Economic growth is not only generated by increasing investment in capital stock and the number of workers, but also by increasing the productivity of production factors due to technological changes and improving the quality of human resources. Thus, investment to improve quality human resources is absolutely necessary. If human capital as a reflection of humans in society and social resources (social capital) is good and of good quality, then this is the main source of strength produced by humans in social life. This means that in increasing good and quality economic growth as a sufficient condition for economic development, community empowerment is definitely needed. According to economic principles, community empowerment is the process of acquiring economic actors to obtain surplus value as human rights involved in production activities. Changes in society towards civil society can be carried out through community empowerment activities in the form of community-oriented education, organizational development, improvement family welfare and people's economic development. This creativity-based economic pattern is then called the creative economy. As a new driver in an economy based on creativity, it is closely related to human resources. Human resources are the main driving force in the creative economy. Meanwhile, the condition of human resources in terms of Currently, the population in Indonesia is large in quantity and in terms of quality, it has relatively improved. In tackling poverty, it is necessary to have a community empowerment program. Women's empowerment is an effort to realize the equal roles, access, and control of women and men in all areas of development. Women's empowerment programs carried out by the government and the community so far are an effort to always realize the creation and distribution of development benefits for men and women in a balanced way. Various steps can be taken to create equality of men and women or gender equality, among others by developing family entrepreneurship so that a balanced role can be realized between men and women in the family to jointly build and develop the family economy in order to achieve family welfare. Although efforts to build gender equality have been carried out for quite a long time, there are still many things and aspects of life that do not reflect the existence of equality between women and men. Lack of attention and intensity and continuity of empowerment programs.

With gender equality, there will be an increase in household income by working women in the productive sector. According to Schumpeter's Economic Theory, economic development is a historical source of economic progress, because the history of economic progress is the history of the development of human creativity. From the economic development that comes from the creativity and competence of entrepreneurs reflected in their activities, high economic growth cannot be avoided. 


\section{Women Empowerment through the Development of Family Entrepreneurship towards a Creative Economy, Puger District, Jember Regency}

To realize this, the role of the community, government and private sector is needed. Therefore, it is necessary to have the right strategy through policies, programs and various supporting activities. Giving empowerment or ability to women has the understanding as an effort made through activities or activities related to the provision of skills or training to housewives which aims to provide an expertise that can help them in fulfilling their life needs. of vulnerability. People in vulnerable groups are those who are in a weak position, easily influenced and assumed to lack the power to help themselves, so they need the help of others. This means that women's empowerment greatly impacts their social functioning ability. Social functioning is closely related to social roles in society. So, someone who is able to play a role in society according to his social status means that person is functioning socially well so as to create a prosperous community life.

Women are one of the causes of the lack of gender equality. Therefore, more active, intensive, serious, and sustainable efforts are needed to build gender equality through women's empowerment programs. Especially when it is associated with the conditions of poverty in this country. Until now, there are many poor families which in itself reflects the number of poor women. Meanwhile, programs to empower poor women so that they can increase their economic independence are still very limited. one up

\section{RESEARCH METHODS}

1. Type of Research

This research is a descriptive study with the support of qualitative and quantitative data, specifically related to women's empowerment in Puger District, Jember Regency through the development of entrepreneurship towards the Creative Economy.

2. Research data

Consists of primary data and secondary data. Primary data in the form of places and events related to the empowerment of poor women are collected through observation, interviews and focus group discussions in stages. Secondary data relates to statistical data on poverty and the results of related studies that have been carried out.

3. Data Analysis Techniques

The data analysis technique uses an interactive model of analysis which has three components, namely data reduction, data presentation, and drawing conclusions (Miles \& Huberman, 1985). Data reduction is a process of selecting, focusing, simplifying and abstracting the rough data in the field notes. Data from the field is in the form of interviews or summary of Focus Group Discussions as well as secondary data which is transcribed in the form of reports and then reduced and selected things that stand out. Data presentation is an assembly of information organization that allows research conclusions to be made. The presentation of data includes various types of matrices, drawings or schematics, networks, activity linkages and tables. Drawing conclusions is an organization of the data that has been collected so that a conclusion can be made.

4. Research Location

This study took place in Mojosari Village, Puger District, Jember Regency. This location was chosen because it is an area that has a high population of female traders

5. Research Procedure

The stages of carrying out the research are broadly carried out as follows:

1. Research and information collecting

2. Describe the profile of women.

3. Analyzing the potential of women traders in developing entrepreneurship

\section{RESULTS AND DISCUSSION}

Puger District is one of the areas in Jember Regency which has the potential of marine and agricultural natural resources. Based on data from the Central Statistics Agency (BPS) shows that in general people work as fishermen with a total population of 2,325 households (Central Statistics Agency, 2020). Based on the following table, it is explained the potential of products produced from the sea obtained by fishermen 
Women Empowerment through the Development of Family Entrepreneurship towards a Creative Economy, Puger District, Jember Regency

Table 1. Processed Fish Catch

\begin{tabular}{|c|c|c|c|c|c|c|c|}
\hline & \multirow[b]{2}{*}{$\begin{array}{l}\text { Kecamatan } \\
\text { Subdistrict }\end{array}$} & \multicolumn{6}{|c|}{ Perahu/Boat } \\
\hline & & $\begin{array}{l}\text { Ikan Kering } \\
\text { Dried Fish }\end{array}$ & $\begin{array}{c}\text { Ikan } \\
\text { Pindang } \\
\text { Preserved } \\
\text { Fish }\end{array}$ & $\begin{array}{l}\text { Asapan } \\
\text { Fogged }\end{array}$ & Terasi & $\begin{array}{l}\text { Kerupuk } \\
\text { Chips }\end{array}$ & $\begin{array}{l}\text { Tepung Ikan } \\
\text { Fish Powder }\end{array}$ \\
\hline & (1) & (2) & (3) & (4) & (5) & (6) & (7) \\
\hline 1. & Puger & 487,75 & 1575,25 & 45,75 & 5,35 & 129,75 & 5,75 \\
\hline 2. & Ambulu & 140,15 & 1325,25 & 15,12 & 2,15 & 37,75 & - \\
\hline 3. & Kencong & 419,75 & 450,25 & 45,13 & 6,05 & 112,25 & - \\
\hline 4. & Gumukmas & 350,25 & 1105,45 & 35,17 & 4,75 & 95,15 & - \\
\hline & Jumlah/Total & 1397,90 & 4456,20 & 141,17 & 18,30 & 374,90 & 5,75 \\
\hline
\end{tabular}

(BPS Puger District, 2020)

The potential generated by the people of the Puger sub-district in general is dried fish, pindang fish and various processed products which show more abundant yields compared to other surrounding sub-districts. Other sub-districts are shown in table 2 below:

Table 2. Total Fishermen Population in Puger District and Surrounding Areas

\begin{tabular}{|c|c|c|c|c|c|c|c|c|c|c|c|}
\hline \multirow{3}{*}{$\begin{array}{l}\text { Kecamatan } \\
\text { Subdistrict }\end{array}$} & \multirow{3}{*}{$\begin{array}{l}\text { Jumlah } \\
\text { Rumah } \\
\text { Tangga } \\
\text { Nelayan } \\
\text { Number of } \\
\text { Fisherman } \\
\text { Family }\end{array}$} & \multirow{3}{*}{$\begin{array}{l}\text { Jumlah } \\
\text { Nelayan } \\
\text { Number of } \\
\text { Fisherman } \\
\text { (Orang) }\end{array}$} & \multicolumn{4}{|c|}{ Perahu/Boat } & \multicolumn{5}{|c|}{ Alat Penangkap Ikan/ Equipment } \\
\hline & & & \multirow[b]{2}{*}{$\begin{array}{l}\text { Besar } \\
\text { Large }\end{array}$} & \multirow[b]{2}{*}{$\begin{array}{l}\text { Sedang } \\
\text { Medium }\end{array}$} & \multicolumn{2}{|c|}{ Jukung } & \multirow[b]{2}{*}{ Payang } & \multirow[b]{2}{*}{$\begin{array}{l}\text { Gill } \\
\text { Net }\end{array}$} & \multirow[b]{2}{*}{$\begin{array}{c}\text { Tramel } \\
\text { Net }\end{array}$} & \multirow[b]{2}{*}{ Perawe } & \multirow[b]{2}{*}{$\begin{array}{c}\text { Lain- } \\
\text { Lain } \\
\text { Others }\end{array}$} \\
\hline & & & & & $\begin{array}{l}\text { Motor } \\
\text { Tempel } \\
\text { Motor }\end{array}$ & $\begin{array}{l}\text { Tanpa } \\
\text { Motor } \\
\text { Without } \\
\text { Motor }\end{array}$ & & & & & \\
\hline (1) & & (3) & (4) & (5) & (6) & (7) & (8) & (9) & (10) & (11) & (12) \\
\hline 1. Puger & 2325 & 10676 & 232 & 263 & 1830 & - & 162 & 1612 & 239 & 594 & 257 \\
\hline 2. Ambulu & 316 & 871 & 25 & - & 291 & - & 25 & 398 & 10 & 81 & 29 \\
\hline 3. Kencong & 154 & 443 & - & - & 153 & - & - & 219 & 4 & 41 & 13 \\
\hline 4. Gumukmas & 151 & 446 & - & - & 153 & - & - & 205 & 183 & 52 & 17 \\
\hline 5. Tempurejo & 21 & 57 & - & - & 20 & - & - & 29 & 1 & 7 & 3 \\
\hline Jumlah/Total & 2967 & 12493 & 257 & 263 & 2447 & - & 187 & 2463 & 437 & 775 & 319 \\
\hline
\end{tabular}

(BPS Puger District, 2020)

Table 2 shows the potential for human resources along with facilities and infrastructure that have better advantages compared to the surrounding area so that based on these data it can be said that Puger District has a competitive advantage compared to other areas in terms of developing marine potential.

Overview General Population

a. Total Population

Table 3.1. Total Population by Type Sex Year 2020

\begin{tabular}{|l|l|l|}
\hline No & Indicator & Amount \\
\hline 1 & Male Resident & $\underline{6.153}$ \\
\hline 2 & Female Resident & $\underline{5.762}$ \\
\hline & Head of family & 3.535 \\
\hline
\end{tabular}

Source: Population Data in Figures for Semester 1 of 2020 


\section{District, Jember Regency}

b. Education Condition

In terms of education, the village of Kirkcaldy has a layout position adjacent to another village and the center of all social activities that exist in the District Puger. So it can be said that the advancementof education in the region have started to develop, the views of the Institute of Education scattered in District Puger ranging from early childhood through high school / vocational school that is not no reason for the parents to send their children for reasons of education centers that are not reachable from home. Mojosari While in the village itself there are several Institutions from kindergarten to the junior high school as follows:

Table 3.2 Number of Educational Institutions in 2020

\begin{tabular}{|c|c|c|c|c|c|}
\hline$\underline{\text { No }}$ & Education Name & $\frac{\text { Amount }}{\text { (units) }}$ & $\underline{\text { Amount }}$ & $\begin{array}{l}\text { Amount } \\
\text { Teacher }\end{array}$ & Information \\
\hline$\underline{1}$ & Taman Kanak-Kanak & $\underline{4}$ & $\underline{305}$ & $\underline{15}$ & \\
\hline 2 & Paud & $\underline{2}$ & $\underline{80}$ & $\underline{7}$ & \\
\hline$\underline{3}$ & $\mathrm{SD} / \mathrm{MI}$ & $\underline{4}$ & $\underline{561}$ & $\underline{53}$ & \\
\hline 4 & MTS & $\underline{1}$ & $\underline{230}$ & $\underline{20}$ & \\
\hline & Amount & 11 & 1176 & 95 & - \\
\hline
\end{tabular}

Source: Mojosari Village Monograph Data 2020

c. Socio- Cultural Conditions

As far as the observations made by the author in the village of Kirkcaldy District of Puger Regency Jember language that is used by the public local language is a mixture of Javanese and Madurese (pandalungan) that are used everyday. For the language of Indonesia society locals also often use such language because people often come across people from outside the region and even outside the city who come to the village of Kirkcaldy are just to buy fish or the other, so that the villagers of Mojosari also accustomed to using the language of Indonesia in everyday life.

d. Number of Population by Type of Work

Table 3.3. Total Population According to Type Works Year 2020

\begin{tabular}{|l|l|l|}
\hline No & eye Livelihoods & Amount \\
\hline 1 & Farmer & 460 \\
2 & Farm Workers & 2,068 \\
3 & Fisherman & 658 \\
4 & Fisherman Buruh & 5.909 \\
5 & entrepreneur & 1.332 \\
6 & Employee & 74 \\
7 & Pegawai Negeri Civil (PNS) & 48 \\
8 & Retired & 27 \\
9 & TNI & 5 \\
10 & Police & 4 \\
11 & so on the other & 16 \\
\hline & \multicolumn{2}{|c}{ Total Amount } \\
\hline
\end{tabular}

Source: Puger Wetan Village Monograph Data 2020 
Women Empowerment through the Development of Family Entrepreneurship towards a Creative Economy, Puger

District, Jember Regency

\section{Principal informant}

Table 3.4.Identitas Informants

\begin{tabular}{|c|c|c|c|c|c|}
\hline No & Additional Informant Name & $\begin{array}{l}\text { Informant's Ini } \\
\text { tials }\end{array}$ & Age & Education Level & $\begin{array}{l}\text { Additional Informant Stat } \\
\text { us }\end{array}$ \\
\hline 1. & Suwani's mother & SW & $\begin{array}{l}35 \text { years } \\
\text { old }\end{array}$ & $\begin{array}{l}\text { senior } \\
\text { High } \\
\text { School }\end{array}$ & Mother Home Appliances \\
\hline 2. & Mother Su & $S$ & $\begin{array}{l}45 \text { years } \\
\text { old }\end{array}$ & SD & Mother Home Appliances \\
\hline 3. & Minten's Mother & M & 36 Years & SD & Mother Home Appliances \\
\hline 4. & Mrs. Nur Jamilah & NJ & 36 Years & $\begin{array}{l}\text { junior } \\
\text { high } \\
\text { school }\end{array}$ & Mother Home Appliances \\
\hline 5. & Wiwit's mother & WT & $\begin{array}{l}45 \text { years } \\
\text { old }\end{array}$ & SD & Mother Home Appliances \\
\hline
\end{tabular}

Source: Primary Data 2020

\section{a. Number of Family Members}

The number of family members of the majority of the Puger community, which incidentally is the Pandalungan community and the level of education is still low, of course in terms of the number of families there is no limit on the number of families. The Puger community, which is still strong in its religious traditions that prioritize the opinion of the kyai, is certainly no stranger to the slogan "many children, lots of sustenance" still attached to the Puger community . It is this which also becomes obstacle to the level of welfare of the people of the level of education and even the level of a profession which is owned by the community. Moreover, the needs that are needed are increasing day by day while the income as a fisherman is only $\pm \mathrm{Rp} 800,000$ per month on average. This is a separate obstacle for family life in the welfare of their families.

b. Informant Status

Informants as fishermen's wives In addition, several additional informants such as population data in the Puger District and Mojosari Village offices which function to cross-check the validity of the data from the informants so that the data can be accounted for in this study.

c. Informant Background

It is common practice for fishermen's wives to pick up their husbands when they come from the sea. That's where the interaction between the women took place, either between wives on a boat or wives on different boats. When one of the fishing boats catches more fish, then this will be a trigger for the wife to ask why her husband doesn't get a lot of catch. Maybe this is not a big problem if only once or twice do not get fish with maximum. If this happens repeatedly will give problems for the wife.

\section{EFFORTS TO INCREASE FISHERMAN'S WIFE'S INCOME}

In research, fishermen's wives struggle to support their families so that they can provide the best for their families to be able to meet all the needs needed by the family by making various efforts, including by conducting job certification, utilizing social networks and utilizing family members to earn income. This kind of strategy is carried out by the wives of traditional fishermen to improve the family economy. 
Women Empowerment through the Development of Family Entrepreneurship towards a Creative Economy, Puger District, Jember Regency

Women's Potential and Opportunities in Developing Business.

\begin{tabular}{|c|c|c|}
\hline NO & DIMENSIONS & DESCRIPTION \\
\hline 1 & $\begin{array}{l}\text { Potential Self-potential in } \\
\text { entrepreneurship }\end{array}$ & $\begin{array}{l}\text { - Self confident personality } \\
\text { - Discipline, both in action and time discipline } \\
\text { - } \text { Creativity has a lot of initiative and has a high } \\
\text { curiosity } \\
\text { - } \quad \text { Have a strong urge to do something to achieve a } \\
\text { - } \text { desire } \\
\text { - } \quad \text { Dake good use of the opportunity } \\
\text { - }\end{array}$ \\
\hline 2 & $\begin{array}{l}\text { Natural Resources Potential: } \\
\text { abundant fish }\end{array}$ & $\begin{array}{l}\text { Able to take advantage of the potential of fish to be } \\
\text { processed in order to have a higher selling value }\end{array}$ \\
\hline 3 & Environmental Opportunities & $\begin{array}{l}\text { Seeing the state of the environment, taking advantage of } \\
\text { the surrounding road }\end{array}$ \\
\hline 4 & Business opportunities & $\begin{array}{l}\text { - The potential of fish to be used as a business } \\
\text { - Look at the surrounding conditions that are used } \\
\text { as a place of business. } \\
\text { - Seeing the situation where there are no sellers of } \\
\text { processed fish crackers such as shredded tuna, } \\
\text { shredded tuna, and roasted shrimp paste, at that } \\
\text { location, the women took advantage of the } \\
\text { situation to sell at that location. }\end{array}$ \\
\hline 5 & Consumer Demand & $\begin{array}{l}\text { - The number of consumer demand, both for own } \\
\text { consumption or for resale. } \\
\text { - } \quad \text { Continue to maintain good product quality. }\end{array}$ \\
\hline
\end{tabular}

\section{CONCLUSIONS AND SUGGESTIONS}

a. Female fishers tardisional doing diversified business to do work extra as a fishmonger if an antecedent as crackers, shredded and paste a very well known so it can meet the needs of day-to-day at the sidelines of the season Western / famine.

b. It is hoped that the government will be more active in helping to improve the economy of the traditional fishing women community.

\section{REFERENCES}

1) Anonymous. (2005). â€œCriteria for the Poorâ€ Kompas, 16 September 2006. Central Bureau of Statistics. (2011). Poverty Rate Analysis and Calculation in 2010 . Jakarta: Central Statistics Agency.

2) Basuki, A. \& Prasetyo, YE (2007). Muzzle Poverty . Surakarta: PATTIRO Surakarta.

3) Central Bureau of Statistics. (2020). Puger District in Figures 2020. Jember Regency.

4) Central Bureau of Statistics. (2021). Jember Regency in Figures 2021. Jember Regency.

5) Darwin, M. (2005). Humanizing the People: Poverty Reduction as the Mainstream of Development. Yogyakarta: Red Thread Publisher.

6) Delise, R. (1997). Used Problem Based Learning in the Classroom . USA: Association for Supervision and Curriculum Development.

7) Friedman, J. (1992). Empowerment the Political of. Alternative Development. Cambridge, Massachusetts: Blackwell Publishers, Three Cambridge Center.

8) Gie, KK (2001). The National Development Program (PROPENAS) 2000-2004 with Gender Insight. Paper on the National Working Meeting for Women's Empowerment Development. Jakarta: BAPPENAS. 
9) Jones, BF, Rasmussen, CM, \& Moftitt, MC (1997). Real Life Problem Solving: A Collaborative Approach to Interdisciplinary Learning . Washington DC: American Psychological Association.

10) Kartasasmita, G. (1996). Development for People: Combining Growth and Equity . Jakarta: CIDESINDO library.

11) Marwanti, S. \& Astuti, D. (2011). A Model for Empowering Poor Women through the Development of Family Entrepreneurship Towards a Creative Economy in Karang Anyar Regency. SEPA, Vol 9 N0 1, September 2012.

12) Miles, MB \& Huberman, AM (1985). Qualitative Data Analysis: A Sourcebook of New Methods. London: Sage Publications.

13) Muttalib, JA (1993). Using the Women's Empowerment Framework, in Moeljarto Tjokrowinoto, et al. Gender and Development Training Materials . UPW State Minister's Office 